\title{
An electrophilic, intramolecularly base-stabilized platinum-antimony complex
}

\author{
Jesse E. Smith, Haifeng Yang, and François P. Gabbaï* \\ Department of Chemistry, Texas A\&M University, College Station, TX 77843-3255.
}

\author{
Supporting information
}

\section{Table of content}

Figure S1. ${ }^{1} \mathrm{H}$ NMR spectrum of $[2-\mathrm{Cl}][\mathrm{Cl}]$ in $\mathrm{CD}_{2} \mathrm{Cl}_{2}$

Figure S2. ${ }^{13} \mathrm{C}\left\{{ }^{1} \mathrm{H}\right\}$ NMR spectrum of $[2-\mathrm{Cl}][\mathrm{Cl}]$ in $\mathrm{CDCl}_{3}$ with the solvent peak truncated.

Figure S3. ${ }^{31} \mathrm{P}\left\{{ }^{1} \mathrm{H}\right\}$ NMR spectrum of $[2-\mathrm{Cl}][\mathrm{Cl}]$ in $\mathrm{CD}_{2} \mathrm{Cl}_{2}$ S3

Figure S4. ${ }^{1} \mathrm{H}$ NMR spectrum of $[2-\mathrm{CyNC}][\mathrm{Cl}]_{2}$ in $\mathrm{CDCl}_{3}$.....

Figure S5. ${ }^{13} \mathrm{C}\left\{{ }^{1} \mathrm{H}\right\}$ NMR spectrum of $[2-\mathrm{CyNC}][\mathrm{Cl}]_{2}$ in $\mathrm{CDCl}_{3}$ with the solvent peak truncated.

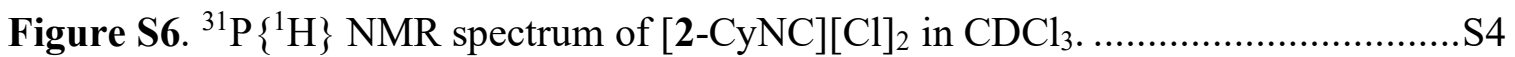

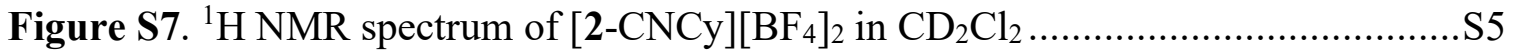

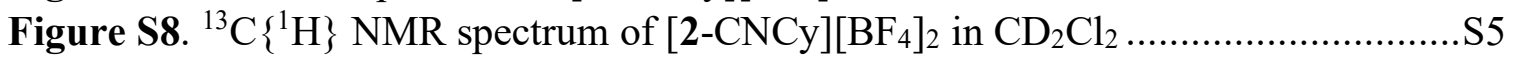

Figure S9. ${ }^{31} \mathrm{P}\left\{{ }^{1} \mathrm{H}\right\}$ NMR spectrum of $[2-\mathrm{CNCy}]\left[\mathrm{BF}_{4}\right]_{2}$ in $\mathrm{CD}_{2} \mathrm{Cl}_{2} \ldots \ldots \ldots \ldots \ldots \ldots \ldots \ldots . . . . . . . . . . . . . . .6 \%$

Figure S10. ${ }^{19} \mathrm{~F}$ NMR spectrum of $[2-\mathrm{CNCy}]\left[\mathrm{BF}_{4}\right]_{2}$ in $\mathrm{CD}_{2} \mathrm{Cl}_{2} \ldots \ldots \ldots \ldots \ldots \ldots \ldots \ldots \ldots . . . . . . . . \ldots$

Figure S11. In situ ${ }^{31} \mathrm{P}\left\{{ }^{1} \mathrm{H}\right\} \mathrm{NMR}$ monitoring of the reaction of $1-\mathrm{Cl}_{2}$ with $\mathrm{AgBF}_{4}$ and 20 equivalents of phenylacetylene at room temperature and at $-40^{\circ} \mathrm{C}$.

Figure S12: In situ ${ }^{31} \mathrm{P}\left\{{ }^{1} \mathrm{H}\right\}$ NMR monitoring of the reaction of [2-Cl] $[\mathrm{Cl}]$ with $\mathrm{AgBF}_{4}$ and 20 equivalents of tetrahydrothiophene in $\mathrm{CD}_{2} \mathrm{Cl}_{2}$.

Figure S13. In situ ${ }^{1} \mathrm{H}$ NMR monitoring of the cyclization reaction between dimethyl 2allyl-2-(2-propynyl)malonate as catalyzed by [2-Cl][Cl] (1 mol\% loading) activated by 2 equivalents of $\mathrm{AgBF}_{4}$.

Figure S14. In situ ${ }^{1} \mathrm{H}$ NMR monitoring of the cyclization reaction between dimethyl 2allyl-2-(2-propynyl)malonate as catalyzed by $1-\mathrm{Cl}_{2}$ activated by 2 equivalents of $\mathrm{AgBF}_{4}$ (5 mol\% loading).

Figure S15. NBO plot (isosurface value: 0.05 ) of the donor-acceptor interactions in [2$\mathrm{Cl}]^{+}$by $\operatorname{lp}(\mathrm{O}) \rightarrow \sigma^{*}(\mathrm{Sb}-\mathrm{C})$

Figure S16. NBO plot (isosurface value: 0.05 ) of the donor-acceptor interactions in [2$\mathrm{Cl}]^{+}$by $\mathrm{lp}(\mathrm{O}) \rightarrow \sigma^{*}(\mathrm{Sb}-\mathrm{C})$.

Figure S17. NBO plot (isosurface value: 0.05 ) of the donor-acceptor interactions in [2$\mathrm{CNCy}]^{2+}$ by $\mathrm{lp}(\mathrm{O}) \rightarrow \sigma^{*}(\mathrm{Sb}-\mathrm{C})$.

Figure S18. NBO plot (isosurface value: 0.05 ) of the donor-acceptor interactions in [2$\mathrm{CNCy}]^{2+}$ by $\mathrm{lp}(\mathrm{O}) \rightarrow \sigma^{*}(\mathrm{Sb}-\mathrm{C})$. 


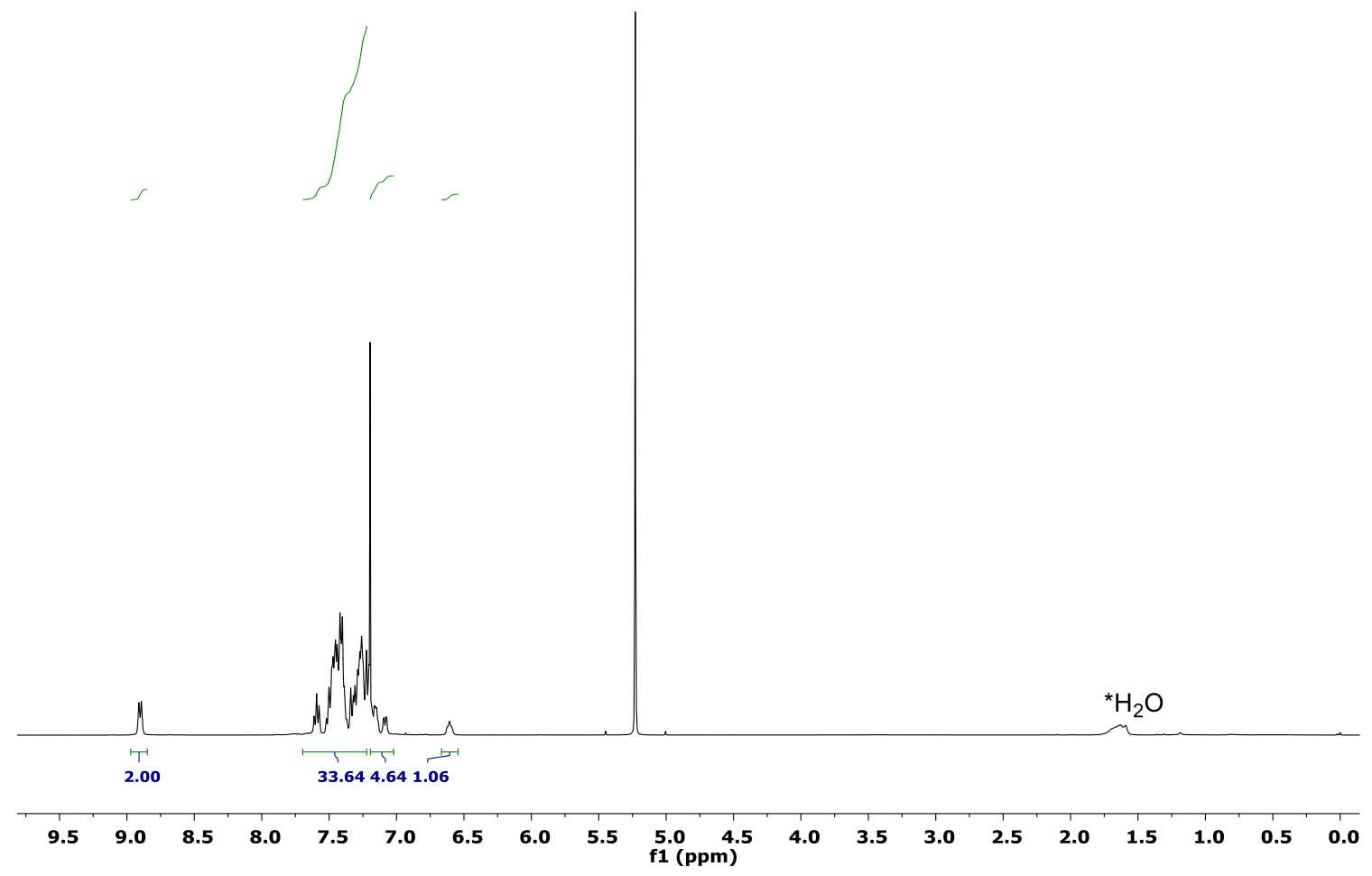

Figure S1. ${ }^{1} \mathrm{H}$ NMR spectrum of $[2-\mathrm{Cl}][\mathrm{Cl}]$ in $\mathrm{CD}_{2} \mathrm{Cl}_{2}$

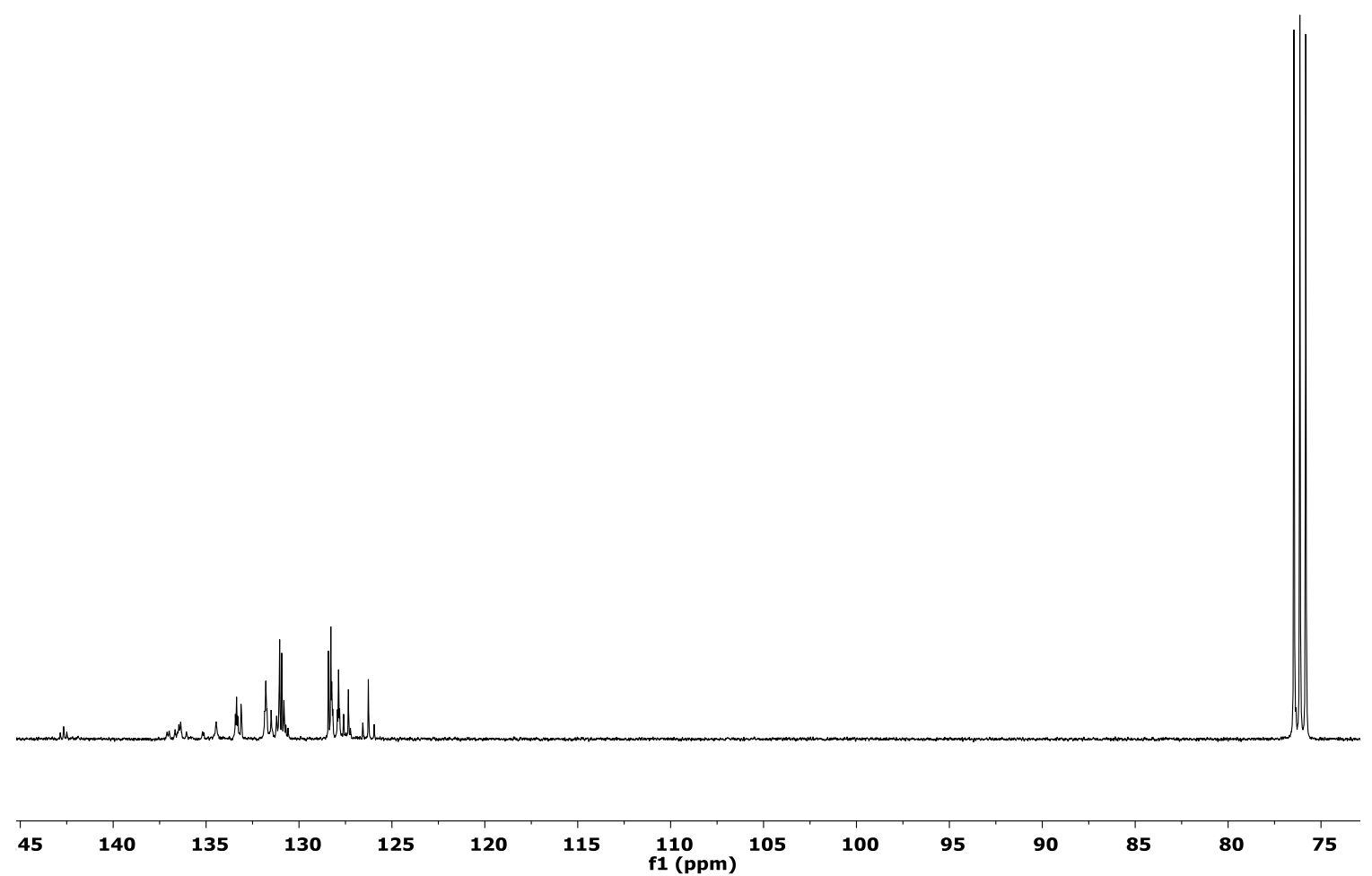

Figure S2. ${ }^{13} \mathrm{C}\left\{{ }^{1} \mathrm{H}\right\}$ NMR spectrum of $[2-\mathrm{Cl}][\mathrm{Cl}]$ in $\mathrm{CDCl}_{3}$ with the solvent peak truncated. 


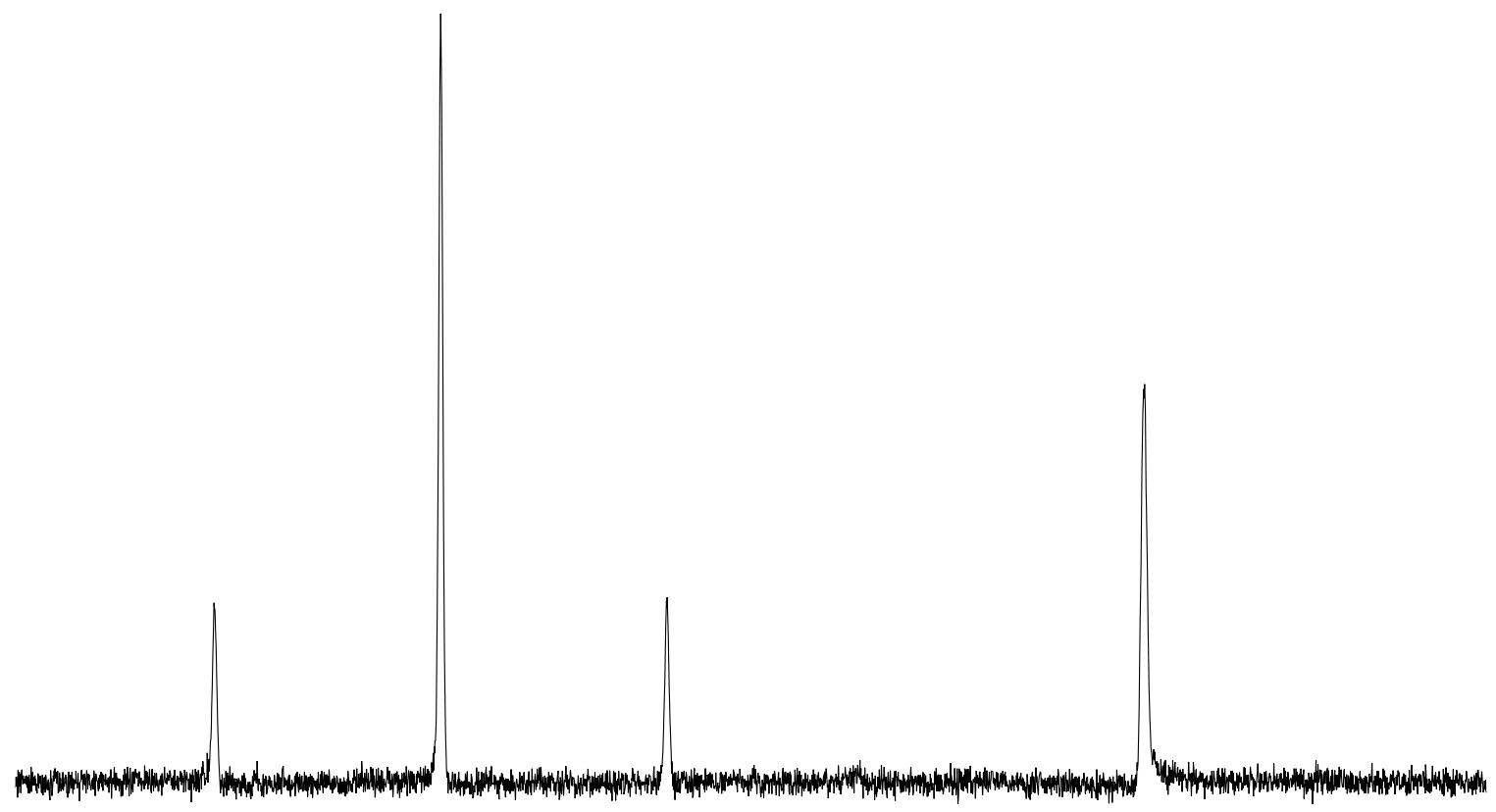

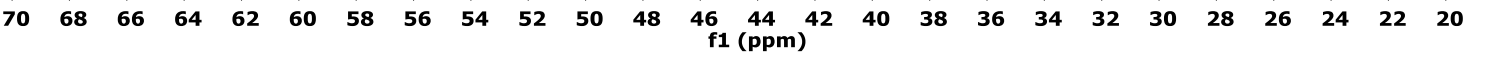

Figure S3. ${ }^{31} \mathrm{P}\left\{{ }^{1} \mathrm{H}\right\}$ NMR spectrum of $[2-\mathrm{Cl}][\mathrm{Cl}]$ in $\mathrm{CD}_{2} \mathrm{Cl}_{2}$

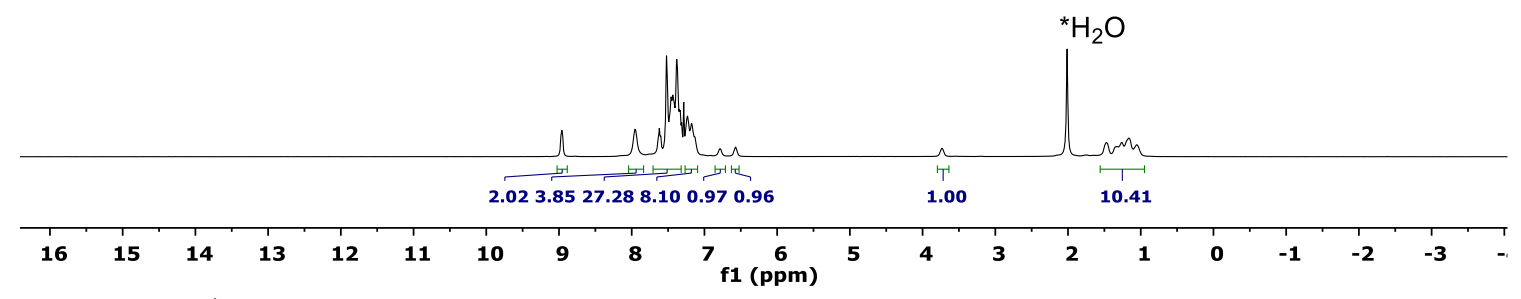

Figure S4. ${ }^{1} \mathrm{H}$ NMR spectrum of $[2-\mathrm{CyNC}][\mathrm{Cl}]_{2}$ in $\mathrm{CDCl}_{3}$ 


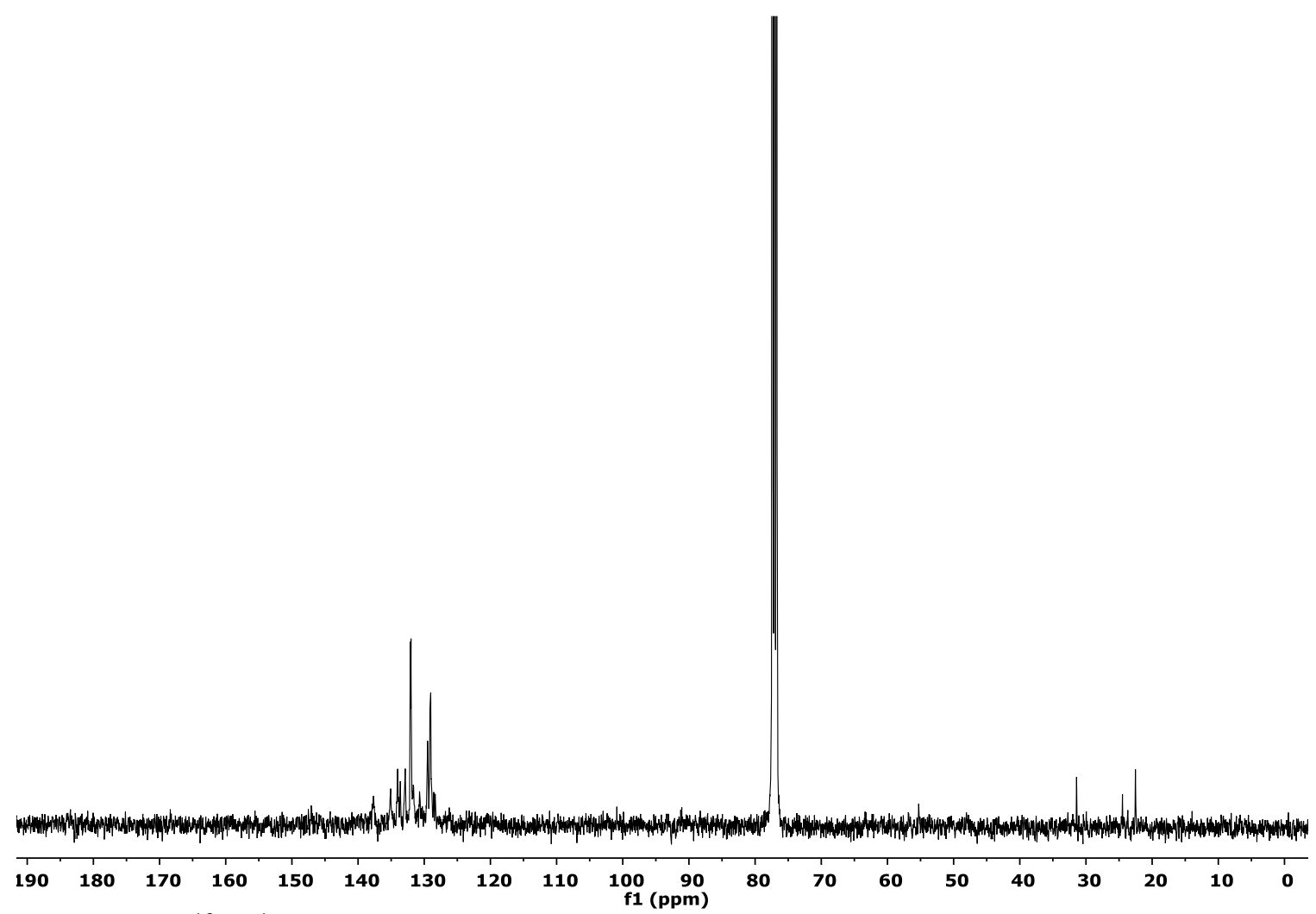

Figure S5. ${ }^{13} \mathrm{C}\left\{{ }^{1} \mathrm{H}\right\}$ NMR spectrum of $[2-\mathrm{CyNC}][\mathrm{Cl}]_{2}$ in $\mathrm{CDCl}_{3}$ with the solvent peak truncated.

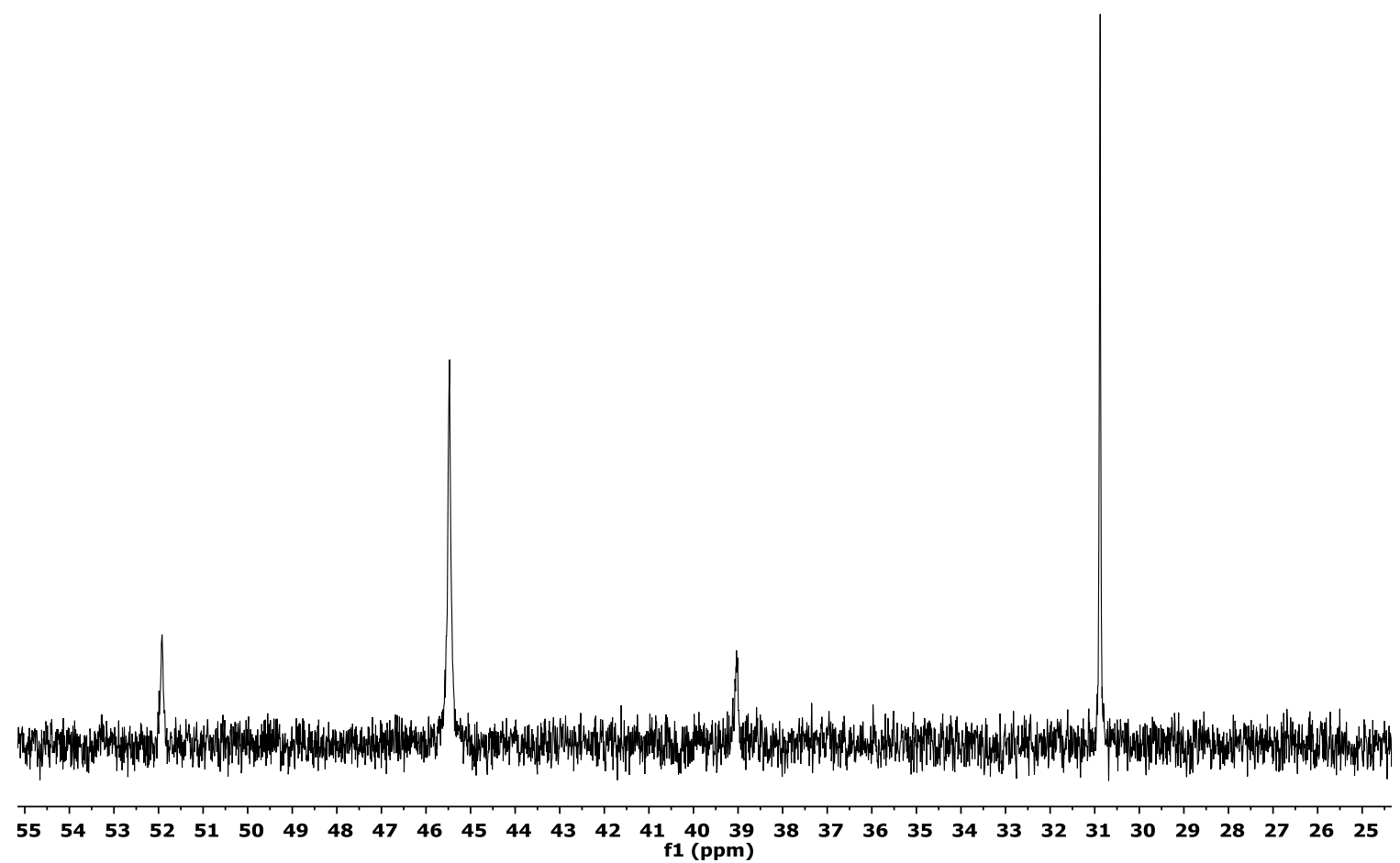

Figure S6. ${ }^{31} \mathrm{P}\left\{{ }^{1} \mathrm{H}\right\} \mathrm{NMR}$ spectrum of $[2-\mathrm{CyNC}][\mathrm{Cl}]_{2}$ in $\mathrm{CDCl}_{3}$. 


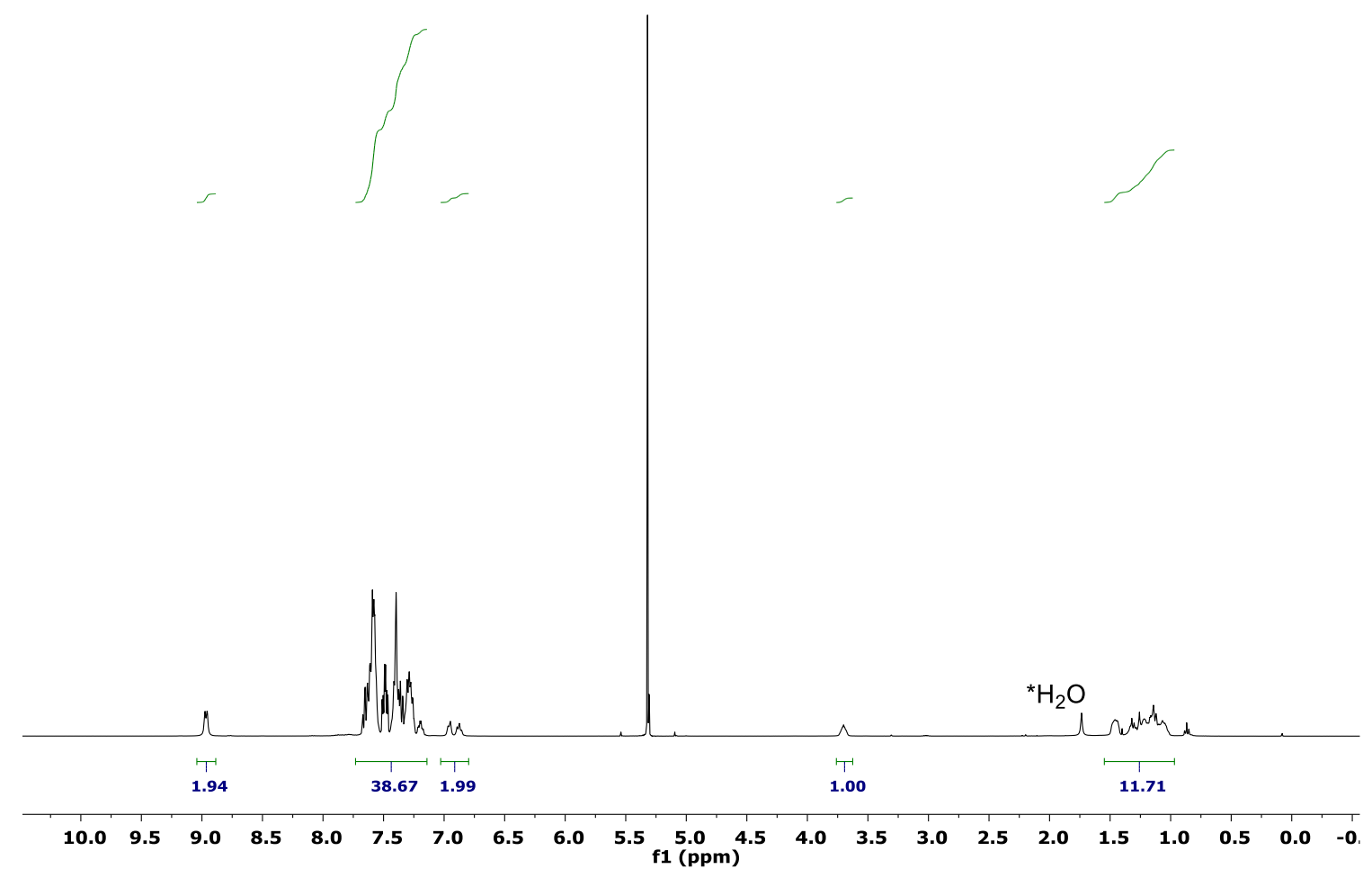

Figure S7. ${ }^{1} \mathrm{H}$ NMR spectrum of $[2-\mathrm{CNCy}]\left[\mathrm{BF}_{4}\right]_{2}$ in $\mathrm{CD}_{2} \mathrm{Cl}_{2}$

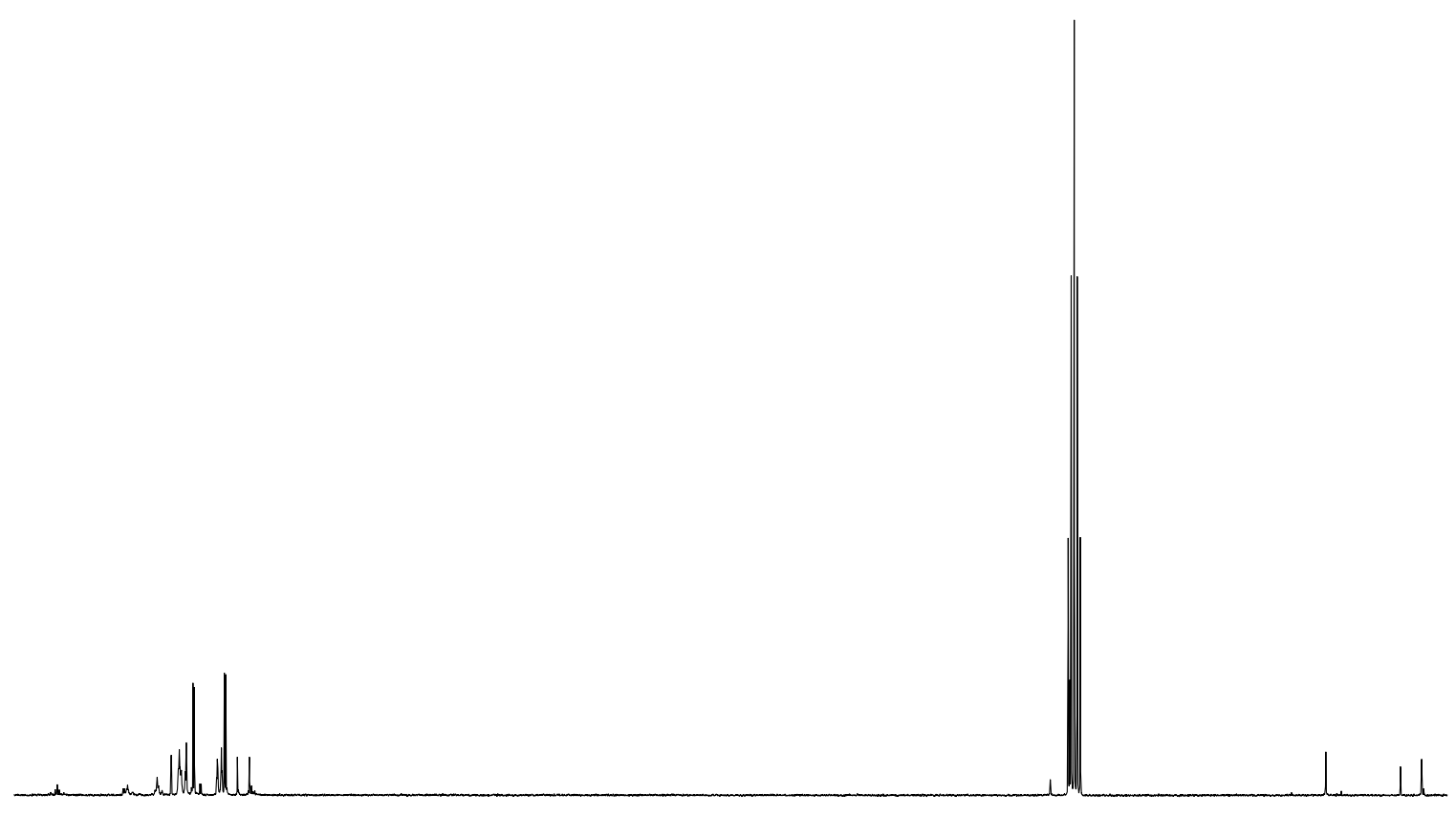

$\begin{array}{lllllllllllllllllllllllllllllllllll}145 & 140 & 135 & 130 & 125 & 120 & 115 & 110 & 105 & 100 & 95 & 90 & \mathbf{f 1}(\mathrm{ppm}) & 75 & 70 & 65 & 60 & 55 & 50 & 45 & 40 & 35 & 30 & 25 & \end{array}$ Figure S8. ${ }^{13} \mathrm{C}\left\{{ }^{1} \mathrm{H}\right\}$ NMR spectrum of $[2-\mathrm{CNCy}]\left[\mathrm{BF}_{4}\right]_{2}$ in $\mathrm{CD}_{2} \mathrm{Cl}_{2}$ 


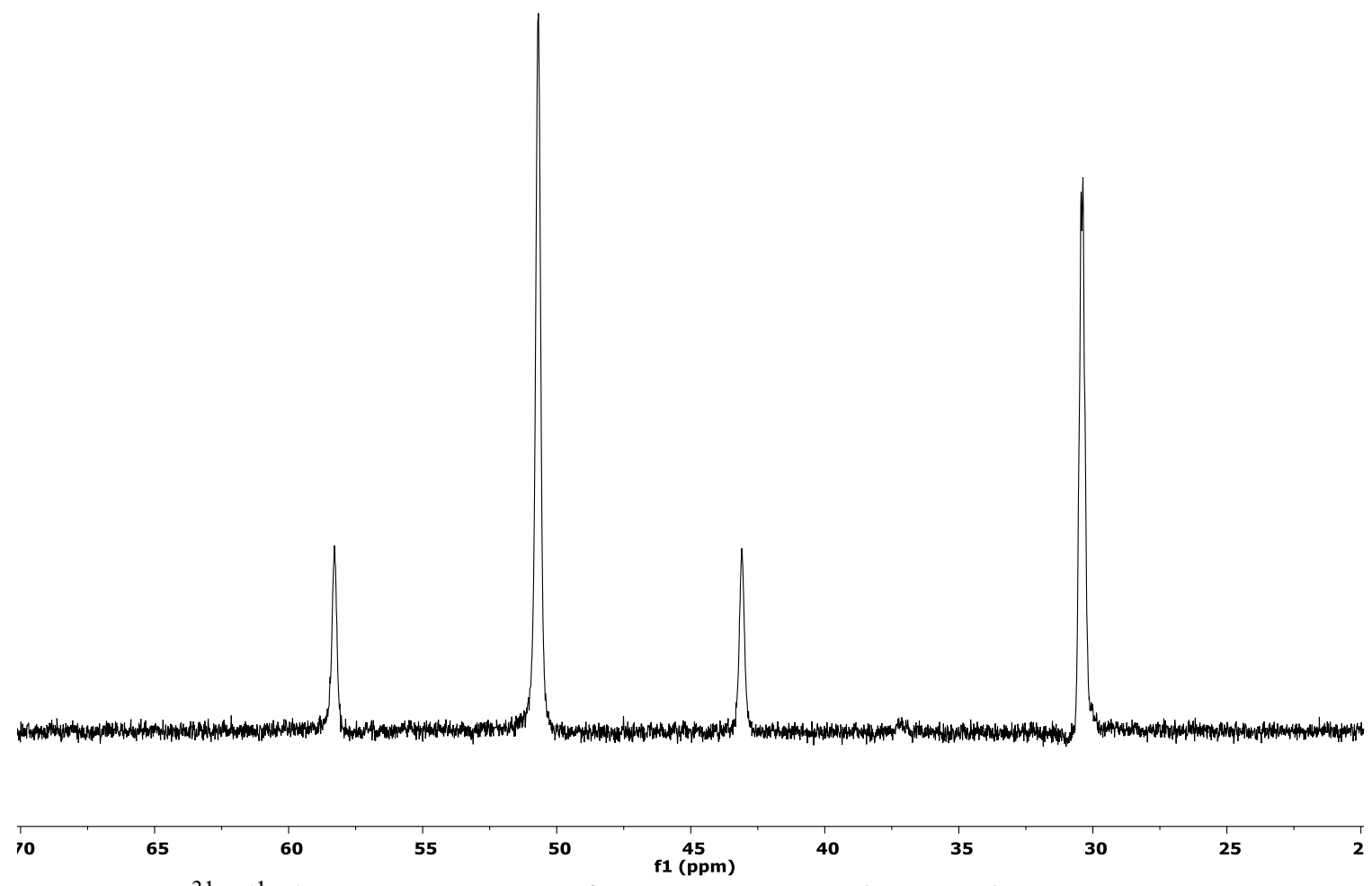

Figure S9. ${ }^{31} \mathrm{P}\left\{{ }^{1} \mathrm{H}\right\}$ NMR spectrum of $[2-\mathrm{CNCy}]\left[\mathrm{BF}_{4}\right]_{2}$ in $\mathrm{CD}_{2} \mathrm{Cl}_{2}$

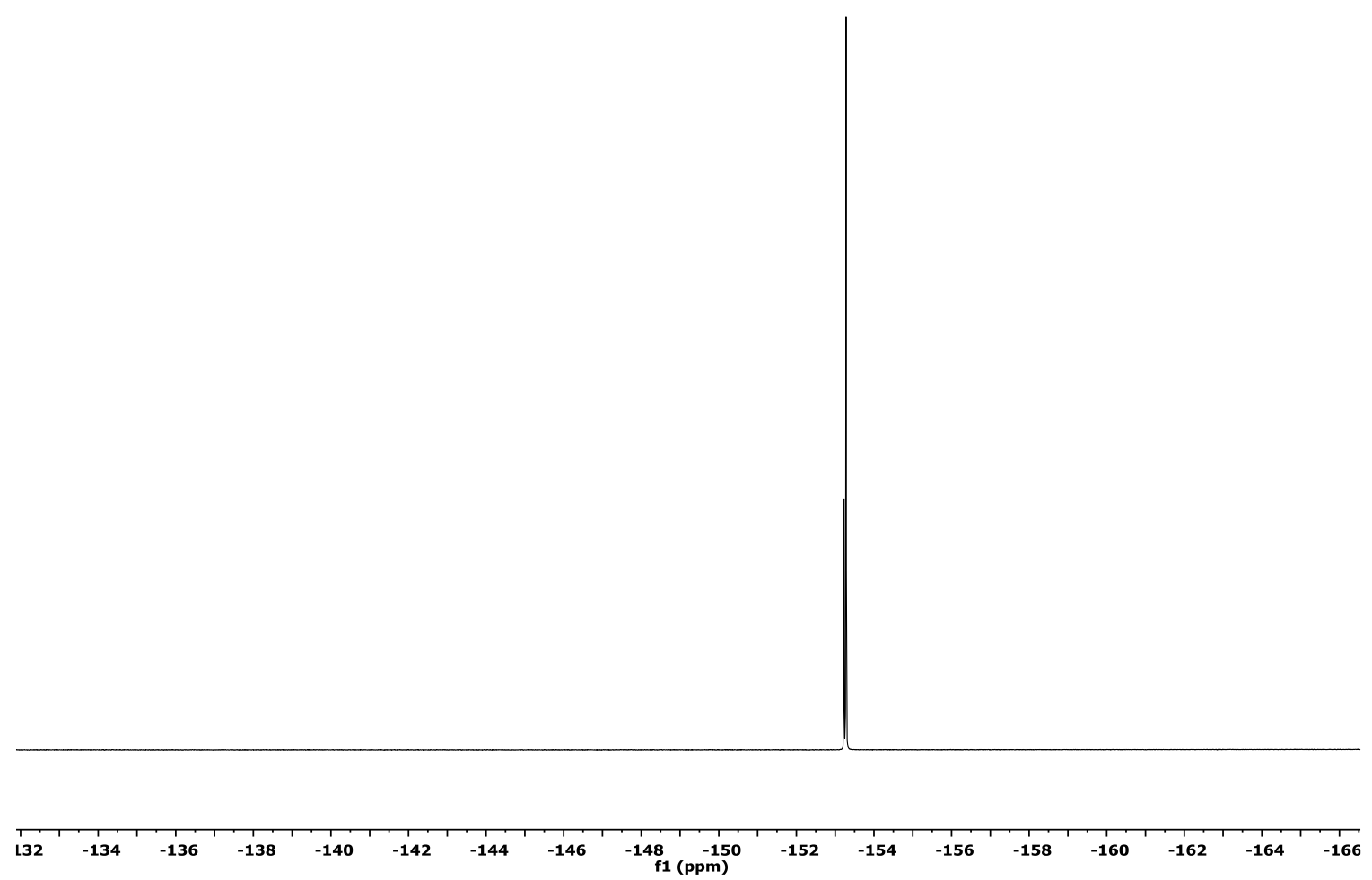

Figure S10. ${ }^{19} \mathrm{~F}$ NMR spectrum of $[2-\mathrm{CNCy}]\left[\mathrm{BF}_{4}\right]_{2}$ in $\mathrm{CD}_{2} \mathrm{Cl}_{2}$ 

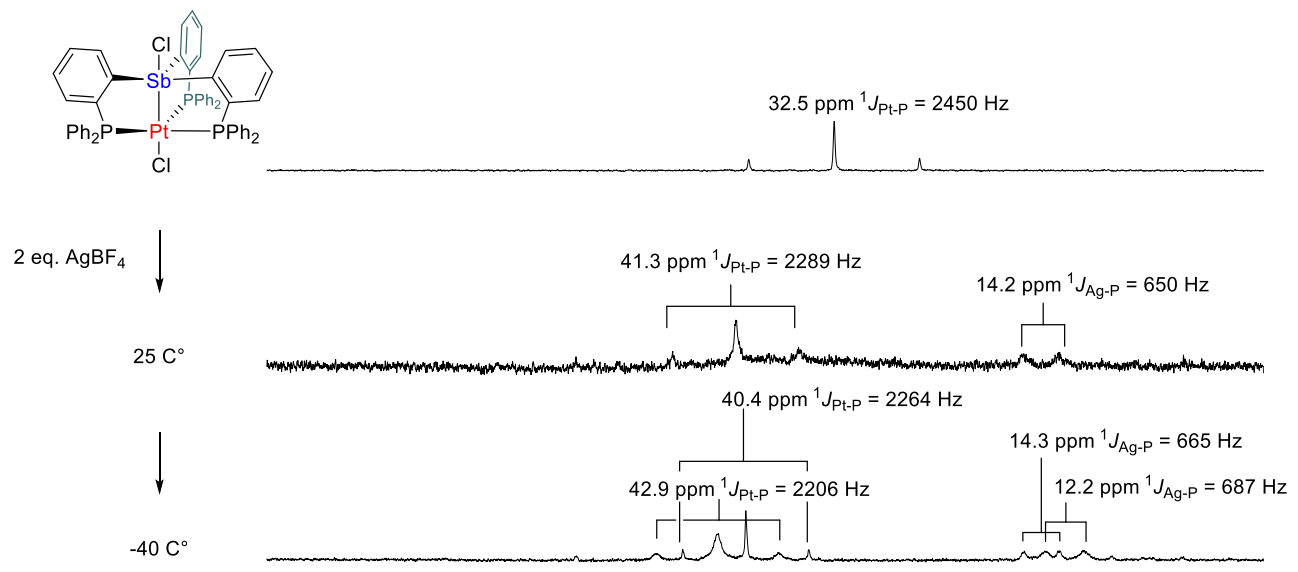

$-40 C^{\circ}$

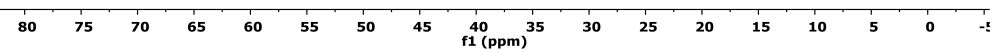

Figure S11. In situ ${ }^{31} \mathrm{P}\left\{{ }^{1} \mathrm{H}\right\}$ NMR monitoring of the reaction of $1-\mathrm{Cl}_{2}$ with $\mathrm{AgBF}_{4}$ and 20 equivalents of phenylacetylene at room temperature and at $-40^{\circ} \mathrm{C}$.

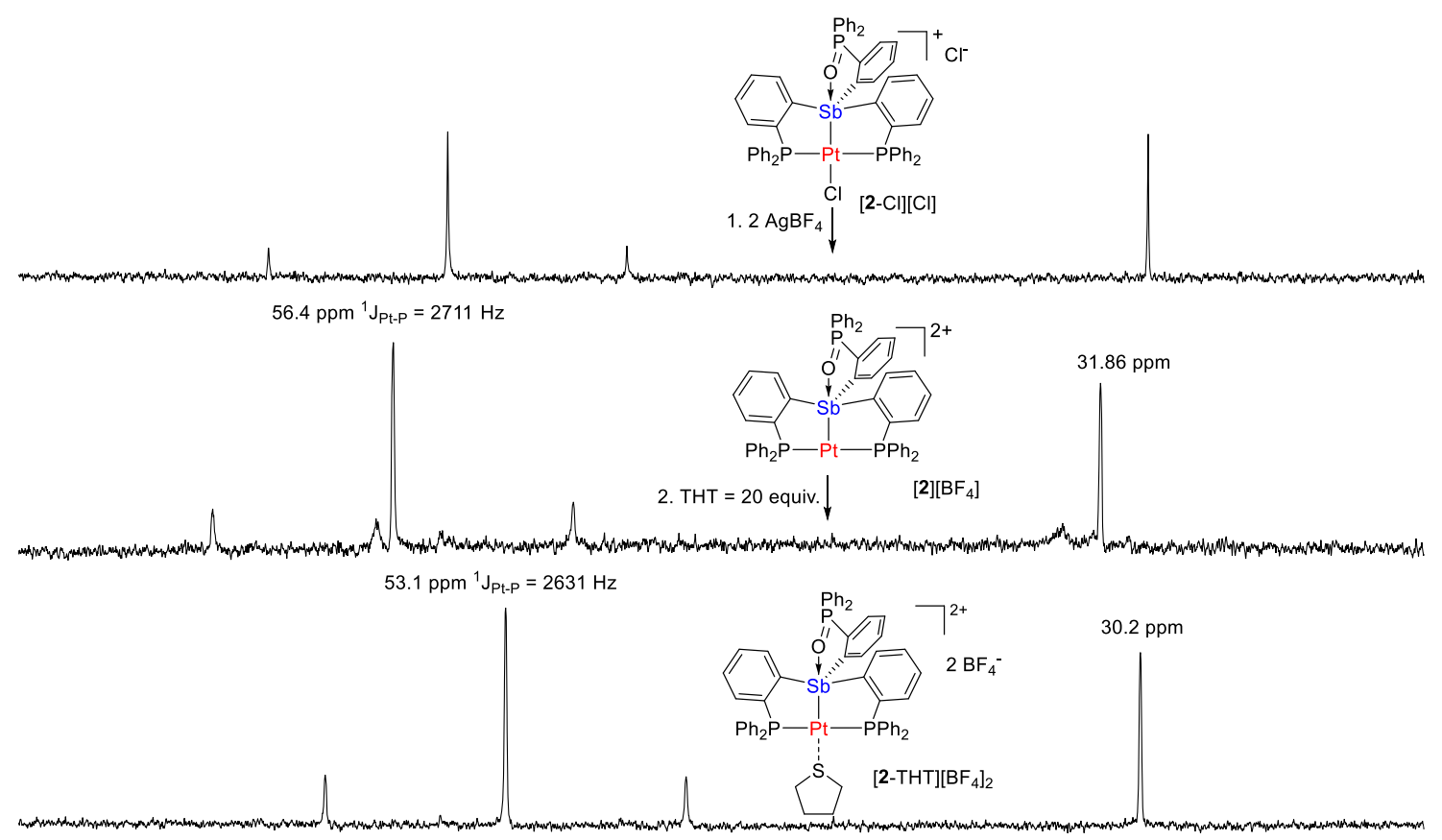

$\begin{array}{lllllllllllllllllllllllllllllllll}70 & 68 & 66 & 64 & 62 & 60 & 58 & 56 & 54 & 52 & 50 & 48 & 46 & 44 & 42 & 40 & 38 & 36 & 34 & 32 & 30 & 28 & 26 & 24 & 22\end{array}$

Figure S12: In situ ${ }^{31} \mathrm{P}\left\{{ }^{1} \mathrm{H}\right\}$ NMR monitoring of the reaction of $[2-\mathrm{Cl}][\mathrm{Cl}]$ with $\mathrm{AgBF}_{4}$ and 20 equivalents of tetrahydrothiophene in $\mathrm{CD}_{2} \mathrm{Cl}_{2}$. 


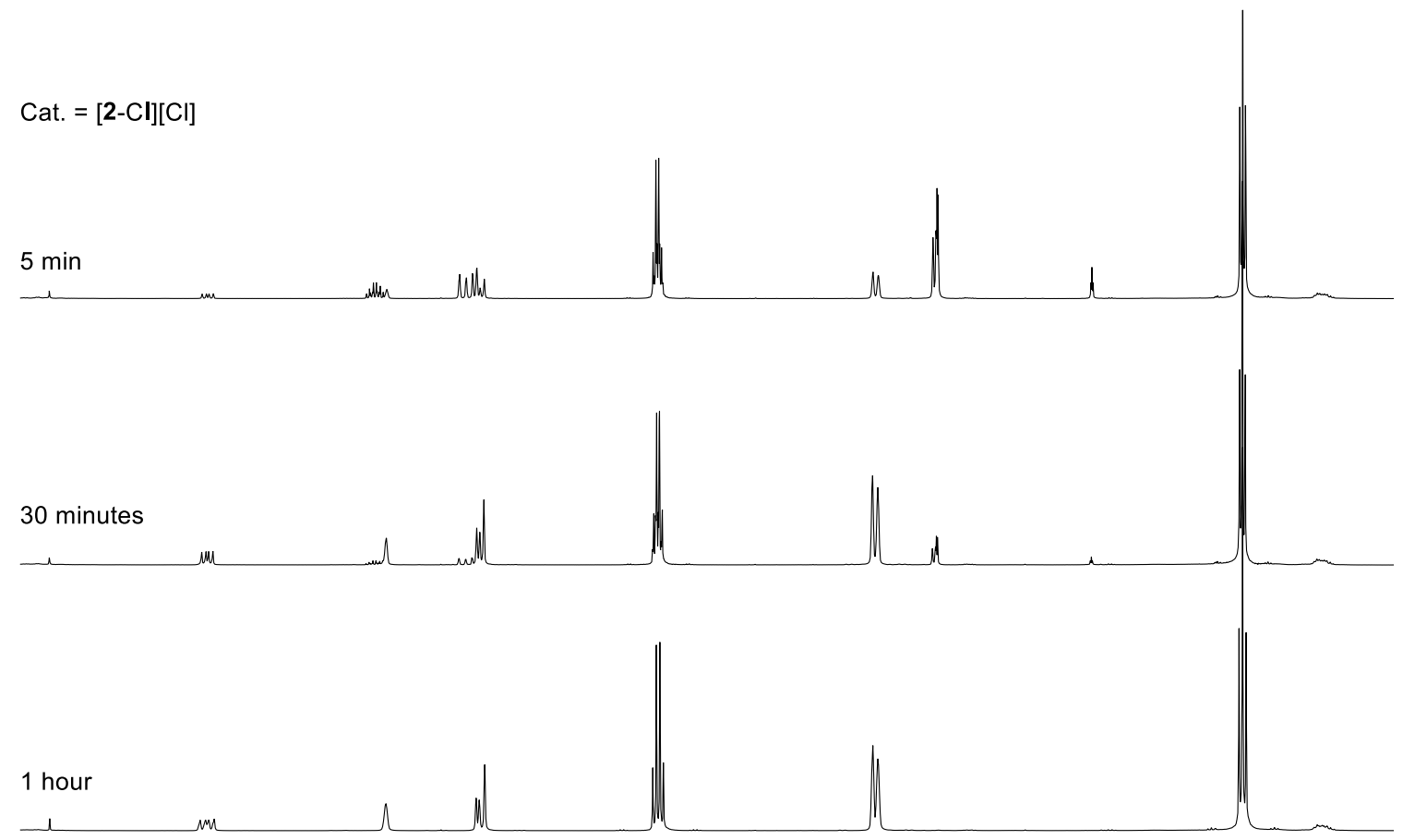

$\begin{array}{llllllllllllllllllllllllllllllllllllllllllllll}7.4 & 7.2 & 7.0 & 6.8 & 6.6 & 6.4 & 6.2 & 6.0 & 5.8 & 5.6 & 5.4 & 5.2 & 5.0 & 4.8 & 4.6 & 4.4 & 4.2 & 4.0 & 3.8 & 3.6 & 3.4 & 3.2 & 3.0 & 2.8 & 2.6 & 2.4 & 2.2 & 2.0 & 1.8 & 1.6 & 1.4 & 1.2 & 1.0 & 0.8 & 0.6\end{array}$

Figure S13. In situ ${ }^{1} \mathrm{H}$ NMR monitoring of the cyclization reaction between dimethyl 2allyl-2-(2-propynyl)malonate as catalyzed by [2-Cl][Cl] (1 mol\% loading) activated by 2 equivalents of $\mathrm{AgBF}_{4}$. 


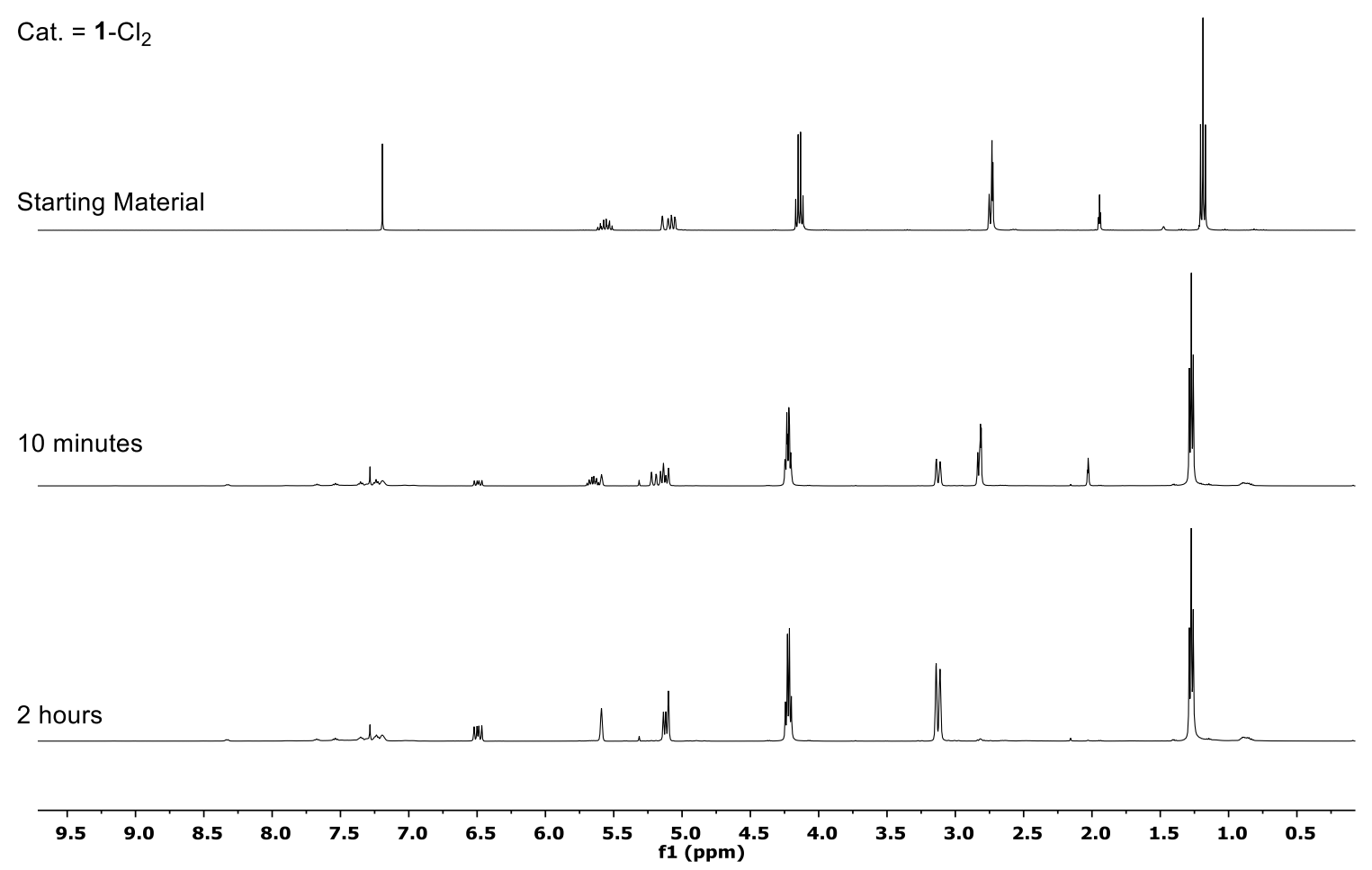

Figure S14. In situ ${ }^{1} \mathrm{H}$ NMR monitoring of the cyclization reaction between dimethyl 2allyl-2-(2-propynyl)malonate as catalyzed by $1-\mathrm{Cl}_{2}$ activated by 2 equivalents of $\mathrm{AgBF}_{4}(5$ mol\% loading). 


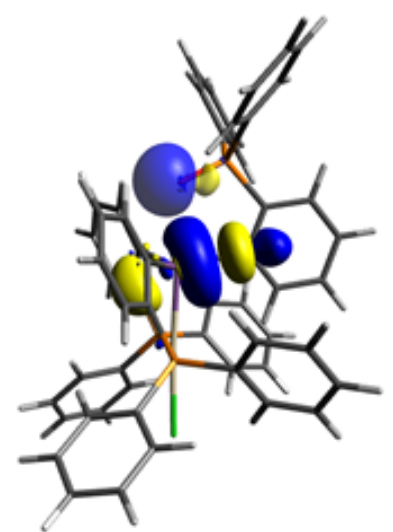

$E(2)=1.85 \mathrm{kcal} / \mathrm{mol}$

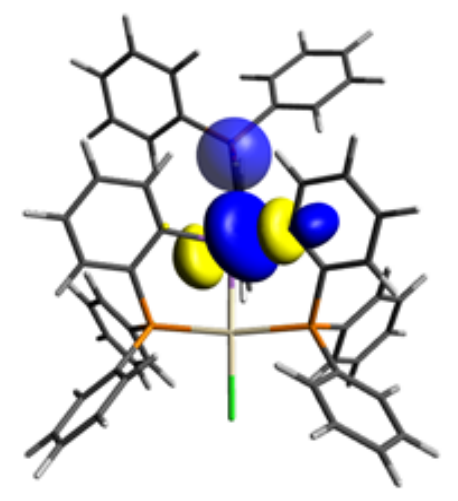

$E(2)=2.29 \mathrm{kcal} / \mathrm{mol}$

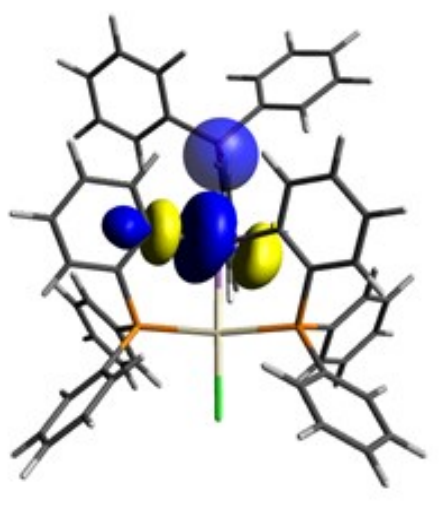

$E(2)=1.46 \mathrm{kcal} / \mathrm{mol}$

Figure S15. NBO plot (isosurface value: 0.05 ) of the donor-acceptor interactions in [2$\mathrm{Cl}]^{+}$by $\mathrm{lp}(\mathrm{O}) \rightarrow \sigma^{*}(\mathrm{Sb}-\mathrm{C})$.

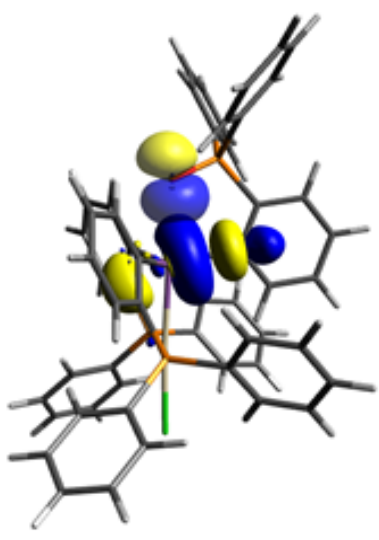

$E(2)=5.62 \mathrm{kcal} / \mathrm{mol}$

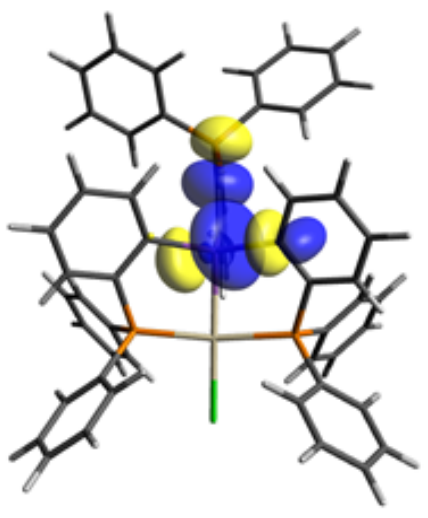

$E(2)=6.24 \mathrm{kcal} / \mathrm{mol}$

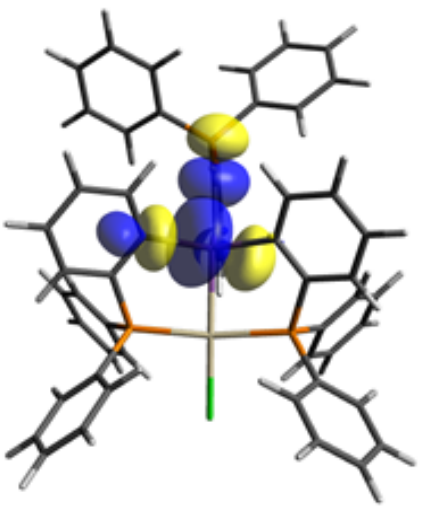

$\mathrm{E}(2)=7.02 \mathrm{kcal} / \mathrm{mol}$

Figure S16. NBO plot (isosurface value: 0.05 ) of the donor-acceptor interactions in [2$\mathrm{Cl}]^{+}$by $\mathrm{lp}(\mathrm{O}) \rightarrow \sigma^{*}(\mathrm{Sb}-\mathrm{C})$. 

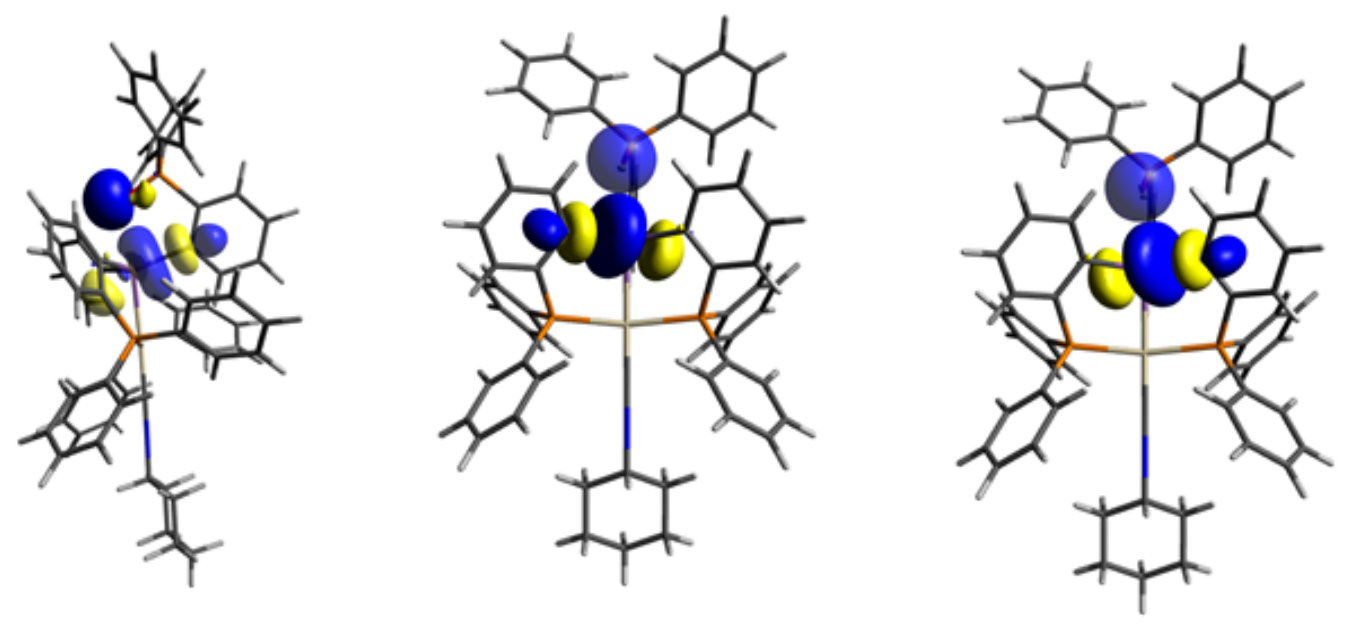

$E(2)=0.82 \mathrm{kcal} / \mathrm{mol}$

$E(2)=0.56 \mathrm{kcal} / \mathrm{mol}$

$E(2)=1.09 \mathrm{kcal} / \mathrm{mol}$

Figure S17. NBO plot (isosurface value: 0.05 ) of the donor-acceptor interactions in [2$\mathrm{CNCy}]^{2+}$ by $\mathrm{lp}(\mathrm{O}) \rightarrow \sigma^{*}(\mathrm{Sb}-\mathrm{C})$.
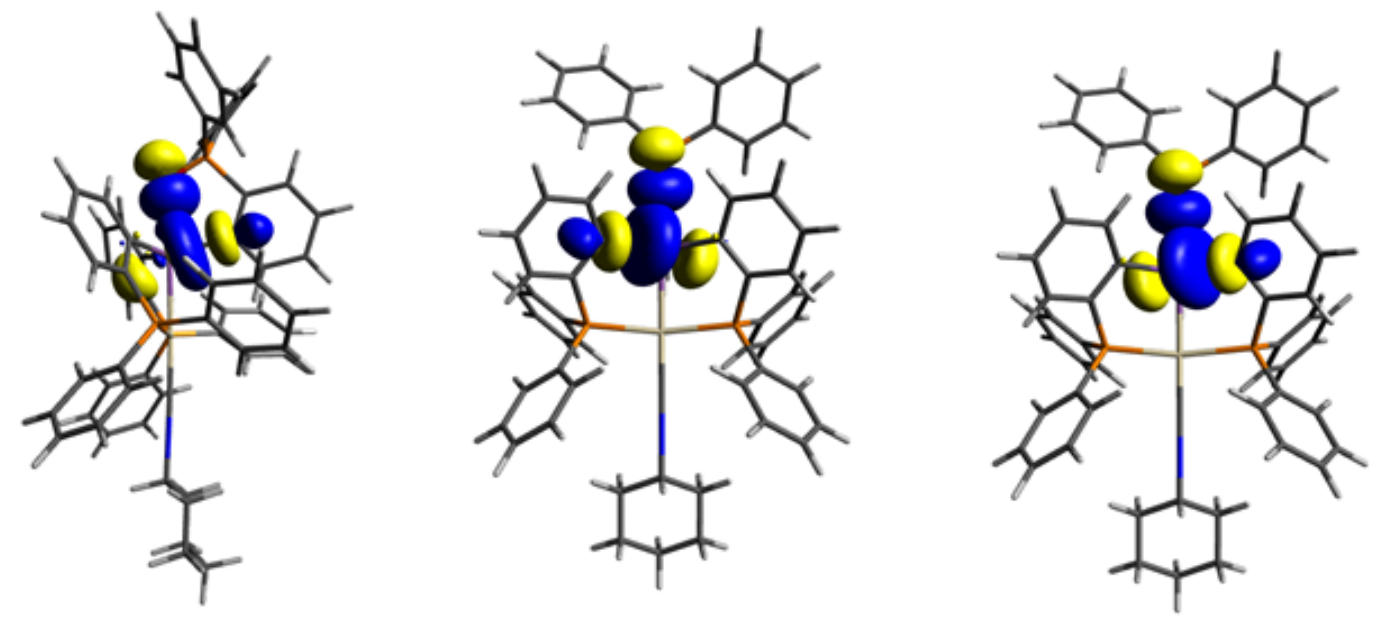

$E(2)=3.07 \mathrm{kcal} / \mathrm{mol}$

$\mathrm{E}(2)=4.70 \mathrm{kcal} / \mathrm{mol}$

$E(2)=3.44 \mathrm{kcal} / \mathrm{mol}$

Figure S18. NBO plot (isosurface value: 0.05 ) of the donor-acceptor interactions in [2$\mathrm{CNCy}]^{2+}$ by $\mathrm{lp}(\mathrm{O}) \rightarrow \sigma^{*}(\mathrm{Sb}-\mathrm{C})$. 